\title{
Performance of Conventional and Innovative Single U-Tube Pipe Configuration in Vertical Ground Heat Exchanger (VGHE)
}

\author{
Adel Eswiasi ${ }^{1}$ and Phalguni Mukhopadhyaya ${ }^{2, *(D)}$ \\ 1 Mechanical Engineering, University of Victoria, Victoria, BC V8W 2Y2, Canada; aeswiasi@uvic.ca \\ 2 Civil Engineering, University of Victoria, Victoria, BC V8W 2Y2, Canada \\ * Correspondence: phalguni@uvic.ca
}

Citation: Eswiasi, A.;

Mukhopadhyaya, P. Performance of Conventional and Innovative Single U-Tube Pipe Configuration in Vertical Ground Heat Exchanger (VGHE). Sustainability 2021, 13, 6384. https:/ / doi.org/10.3390/su13116384

Academic Editor: Mostafa Ghasemi Baboli

Received: 30 April 2021

Accepted: 31 May 2021

Published: 4 June 2021

Publisher's Note: MDPI stays neutral with regard to jurisdictional claims in published maps and institutional affiliations.

Copyright: (C) 2021 by the authors. Licensee MDPI, Basel, Switzerland. This article is an open access article distributed under the terms and conditions of the Creative Commons Attribution (CC BY) license (https:/ / creativecommons.org/licenses/by/ $4.0 /)$.

\begin{abstract}
A ground source heat pump system (GSHP) with a ground heat exchanger (GHE) is a renewable and green technology used for heating and cooling residential and commercial buildings. An innovative U-Tube pipe configuration is suggested to enhance the heat transfer rate in the vertical ground heat exchanger (VGHE). Laboratory experiments are conducted to compare the thermal efficiency of VGHEs with two different pipe configurations: (1) an innovative U-Tube pipe configuration (single U-Tube with two outer fins) and (2) a single U-Tube. The results show that the difference between the inlet and outlet temperatures for the innovative U-Tube pipe configuration was $0.7^{\circ} \mathrm{C}$ after $60 \mathrm{~h}$, while it was $0.4^{\circ} \mathrm{C}$ for the single U-Tube after the same amount of time. The borehole thermal resistance for the innovative U-Tube pipe configuration was $0.680 \mathrm{~m} \cdot \mathrm{K} / \mathrm{W}$, which is $29.22 \%$ lower than that of the single U-Tube. The heat exchange rate in the innovative U-Tube pipe configuration is increased by $57.95 \%$ compared to the conventional single U-Tube. Measured ground temperatures indicate that compared to single U-Tube pipe configuration, the innovative U-Tube pipe configuration has superior heat transfer performance. Based on the experimental results presented in this paper, it was concluded that increasing the surface area significantly by introducing external fins to the U-Tube enhances the heat transfer rate, resulting in increased thermal efficiency of the VGHE.
\end{abstract}

Keywords: vertical ground heat exchanger; external fin; thermal response test; effective ground thermal conductivity

\section{Introduction and Background}

A ground source heat pump system (GSHP) is an ecofriendly technology utilized for heating and cooling houses and commercial buildings. GSHP technology exploits the constant ground temperature over the year to extract heat from buildings and transfer it into the ground in summer, as well as to extract heat from the ground and transfer it into the buildings in winter [1,2]. The GSHP system is constructed by connecting a heat pump with a vertical ground heat exchanger (VGHE). Since the second half of the 1990s, Thermal Response Tests (TRTs) have been used to measure ground thermal properties (borehole thermal resistance and effective ground thermal conductivity) and characterize the efficiency of VGHEs. Researchers have suggested different approaches to measure ground thermal properties in the field, and a number of mobile experimental apparatuses have been built in different countries to carry out these measurements [3]. The initial capital cost of installing the GSHP systems is a significant consideration in VGHE design. Hence, there are opportunities for designers to do more work in this area and suggest new pipe configurations to increase the heat transfer rate in the VGHEs and thus decrease the depth and cost of borehole installation. During the past few decades, several researchers conducted studies to improve the thermal performance of VGHEs by decreasing the thermal resistance between the borehole wall and the ground as much as possible. These studies were based on either numerical or experimental models, the latter includes a small-scale apparatus in the laboratory or a full-scale field investigation. 
Gu and O'Neal (1998) built a small-scale single U-Tube VGHE in the laboratory to estimate the effects of backfills (bentonite/masonry sand and bentonite/copper powder) on the heat transfer performance of a single U-Tube VGHE. The single U-Tube copper pipe (inner diameter, $4.8 \mathrm{~mm}$; outer diameter, $6.4 \mathrm{~mm}$; length, $1.2 \mathrm{~m}$ ) was inserted in a metal tank. The obtained results showed that backfill materials have an influence on the thermal performance of single U-Tube VGHEs [4].

To determine the effects of another factor, Pahud and Matthey (2001) conducted TRTs for the double U-Tube VGHEs, with and without spacers, to estimate the influence of these spacers on the borehole thermal resistance. The borehole thermal resistances of double U-Tube VGHEs with and without spacers were $0.141 \mathrm{~m} \cdot \mathrm{K} / \mathrm{W}$ and $0.143 \mathrm{~m} \cdot \mathrm{K} / \mathrm{W}$, respectively [5]. Zeng et al. (2003) suggested an analytical solution considering the influence of fluid axial convective heat transfer on pipe configurations of VGHEs. Two different configurations, single and double U-Tube, of VGHEs were examined by using this method. The results showed that the borehole thermal resistance of double U-Tube VGHE was lower than the single U-Tube VGHE [6].

Only one study conducted by Esen and Inalli (2009) showed the effects of three different borehole depths $(30 \mathrm{~m}, 60 \mathrm{~m}$, and $90 \mathrm{~m})$ on the thermal performance of VGHEs. The results showed that the $90 \mathrm{~m}$ depth borehole heat exchanger had stronger performance than those with the depths of $60 \mathrm{~m}$ and $30 \mathrm{~m}$. It was also noticed that the thermal resistance values for the single U-Tube VGHE with depths of $60 \mathrm{~m}$ and $90 \mathrm{~m}$ were 0.05 and $0.03 \mathrm{~m} \cdot \mathrm{K} / \mathrm{W}$, respectively [7].

To determine the effects of different pipe configurations on the thermal performance of VGHE, Acuña and Palm (2010) proposed a new pipe configuration, coaxial (pipe-inpipe) VGHE, and it compared with conventional single U-Tube. The outer pipe was in direct contact with the surrounding bedrock. The results showed that the heat transfer performance of the coaxial VGHE was superior to the conventional single U-Tube VGHE [8]. Another field study was conducted by Lee et al. (2011) to estimate the thermal efficiency of two different pipe configurations, the common U-Tube type and a new three-pipe type GHE. The thermal efficiency of the new three-pipe type configuration was higher than that of the conventional single U-Tube type [9]. In a study that set out to determine the effects of three different types—coaxial, double U-Tube, and U-Tube VGHEs-in Oklahoma City, OK, USA, Beier and Ewbank (2012) found that the best option to reduce the thermal resistance of the borehole was the double U-Tube, followed by the single U-Tube, and finally the coaxial type [10]. In the same year, a field study was performed by Desmedt et al. (2012) to estimate the influence of two different pipe configurations (single U-pipe and double U-pipe) on the efficiency of the VGHEs. The thermal resistance of the double U-Tube VGHE was $0.162 \mathrm{~m} \cdot \mathrm{K} / \mathrm{W}, 52 \%$ lower than the single U-Tube VGHE [11]. To improve the thermal performance of VGHEs, a numerical study was investigated by Haddada and Miyara (2014) to estimate the impacts of pipe numbers inside the borehole on the performance of VGHEs. The four different pipe configurations examined were U-Tube, multi-tube, three-tube, and four-tube. The heat exchange rate increased between the boreholes and the ground due to an increase in the number of inlet tubes inside the borehole [12].

Kramer and Basu (2014) built an experimental apparatus in the laboratory to study the effect of thermal loading on load displacement behavior of the model geothermal pile. The polyvinylchloride (PVC) U-Tube pipe was installed in a sand tank (length, $1.83 \mathrm{~m}$; depth, $1.83 \mathrm{~m}$; width, $1.83 \mathrm{~m}$ ). The U-Tube pipe consisted of two PVC pipes that had an inner diameter of $12.4 \mathrm{~mm}$ with a length of $1.22 \mathrm{~m}$ [13]. Shirazi and Bernier (2014) established a small-scale experimental apparatus with a borehole Plexiglas pipe (length, $1.23 \mathrm{~m}$ ) inserted at the center from the top of the sand tank (length, $1.35 \mathrm{~m}$; diameter, $1.4 \mathrm{~m}$ ). The TRT was $73 \mathrm{~h}$ for the heat injection and 5 days to let the sand return to its initial ground temperature. It was reported that the borehole thermal resistance for the single U-Tube VGHE was $0.61 \mathrm{~m} \cdot \mathrm{K} / \mathrm{W}$ [14]. Another small scale VGHE study was conducted by Erol and François (2014) to estimate the effects of backfill materials on the thermal performance of the VGHE. Two parallel pipes were inserted in the $1 \mathrm{~m}$ length of the VGHE in the sand tank of $1 \mathrm{~m}^{3}$. 
Two heat pumps were used to pump the water to pipes at $12{ }^{\circ} \mathrm{C}, 15^{\circ} \mathrm{C}$ inlet and outlet of water temperatures, respectively. The initial temperature of the sand was $20^{\circ} \mathrm{C}$ [15]. One year later, Cimmino and Bernier (2015) built the experimental setup consisting of a $400 \mathrm{~mm}$ tall borehole inserted in center and top of the sand tank (length, $1.35 \mathrm{~m}$; diameter, $1.4 \mathrm{~m}$ ). The single U-Tube copper pipe was inserted in the borehole. The objective of this study was to measure the borehole wall temperature at various depths and different times during the TRT. The results showed that the borehole wall temperature increased with an increase in the duration of the TRT [16].

Liu et al. (2015) suggested a new VGHE design with three inlet pipes and one outlet (3Itype) and compared its performance to the single and double U-Tube VGHEs. Experimental results showed that the thermal resistance of the 3I-type was $31 \%$ and $15.8 \%$ lower than the single and double U-Tubes, respectively [17]. In an analysis of the influences of the different pipe material properties (copper and high density polyethylene pipes) on the performance of VGHEs, Ramadan (2016) found that the performance trend remains the same for both copper and high density polyethylene pipes in a ground heat exchanger [18]. Another field was conducted by Chang and Kim (2016) to estimate the influence of two different pipe configurations, single U-Tube and double U-Tube, on the thermal performance of VGHEs. The thermal resistance of the single and double U-Tubes was $0.130 \mathrm{~m} \cdot \mathrm{K} / \mathrm{W}$ and $0.081 \mathrm{~m} \cdot \mathrm{K} / \mathrm{W}$, respectively [19]. In a numerical study investigated by Luo et al. (2016), the thermal efficiency of four different pipe configurations (double- $U$, triple- $U$, double-W, and spiral) was estimated. The triple U-Tube had a higher thermal efficiency, followed by the double- $W$, the spiral type, and the double U-Tube. The results also indicated that the double-W type had the lowest economic performance, followed by the spiral type, the double-U type, and the triple-U type [20]. Two years later, another numerical study was investigated by Serageldin et al. (2018) to improve the performance of VGHE by suggesting an innovative U-Tube pipe configuration (an oval U-Tube), and it compared a conventional single U-Tube. The results showed that the thermal resistance of the oval U-Tube was $0.125 \mathrm{~m} \cdot \mathrm{K} / \mathrm{W}$, and $15.8 \%$ lower than the conventional single U-Tube [21]. A field study was conducted by Bae et al. (2019) to estimate the thermal performance for four different pipe types (high-density polyethylene (HDPE) type, HDPE-nano type, spiral fin type, and coaxial type). The results showed that the best option to reduce the thermal resistance of the borehole was the spiral fin type $(0.181 \mathrm{~m} \cdot \mathrm{K} / \mathrm{W})$, followed by the HDPE-nano type $(0.181 \mathrm{~m} \cdot \mathrm{K} / \mathrm{W})$, HDPE type $(0.183 \mathrm{~m} \cdot \mathrm{K} / \mathrm{W})$, and a coaxial type $(0.306 \mathrm{~m} \cdot \mathrm{K} / \mathrm{W})$ [22].

A recent laboratory study was conducted by $\mathrm{Li}$ et al. (2018) to estimate the effects of ground stratification on the performance of GHEs. Two U-Tube copper GHEs were installed in a sand tank (depth, $6.25 \mathrm{~m}$; length, $1.5 \mathrm{~m}$; width, $1 \mathrm{~m}$ ), and the sand tank was filled with sand and clay. The two U-Tube pipe consisted of two copper pipes that had an inner diameter of $5 \mathrm{~mm}$ and diameter outer of $5.5 \mathrm{~mm}$ with a length of $6.25 \mathrm{~m}$. The results showed that an increase in the ground heat injection rates leads to a significant increase in the effects of ground stratification [23]. One year later, Liang et al. (2019) constructed an experimental setup with a small-scale spiral-tube copper pipe VGHE inserted in the metal container (diameter, $0.8 \mathrm{~m}$; height, $1.1 \mathrm{~m}$ ) setup to investigate the influences of two parameters (volume flow rate and backfill materials) on the thermal performance of a small-scale spiral-tube VGHE. The results showed that the heat exchange rate in the spiral-tube VGHE in blend added to the sand with different Reynolds numbers (3000-8000) enhanced by $20-31 \%$ compared to the native sand [24].

To sum up, the previous paragraphs present a comprehensive review of the efficiency of ground heat exchangers (GHE) in heat pump systems. Increasing the efficiency of the GHE may lead to decreased borehole depths and installation costs. Hence, the identification and optimization of design and operation parameters that can reduce the borehole depth are among the most important design challenges. To deal with these challenges, various researchers have conducted several studies to improve the heat transfer efficiency of GHEs. However, there are still opportunities for engineers to suggest new pipe configurations that can increase the surface area of the pipe and heat transfer rate in GHEs. One of the most 
attractive solutions to increase the heat transfer rate in VGHEs is to increase the surface area of the pipe configuration, which could lead to higher heat exchange capacity of VGHEs. It is well known that heat transfer from a surface can be increased by attaching external fins (i.e., extended surfaces). However, research activities reported in the literature do not provide any information about the performance of GHEs with external fins. Therefore, this research initiative investigates the impacts of external fins on the heat transfer capacity of VGHEs.

In this paper, an innovative U-Tube pipe configuration (conventional single U-Tube with two outer fins) is proposed to improve the thermal performance of VGHE by increasing the surface area for a higher heat transfer rate. Fins or extended surfaces are used to enhance heat transfer by conduction through the solid and also by convection from the solid boundaries. Fins of many shapes such as rectangular, trapezoidal, concave, etc. could be used to enhance the heat transfer rate. The concave shape has a higher heat transfer rate than the rectangular or trapezoidal shape, and the rectangular shape is more efficient in transferring heat than the trapezoidal shape [25]. In this study, the fins were planned to be designed in a concave shape, but then it was decided to change them to a trapezoidal shape because the tools available in the workshop were not suitable for producing fins in a concave shape. Another secondary reason to select the trapezoidal shape is its small tip at the end of the fin. This means it can be a good option to increase the fin length without touching the borehole wall, compared to the rectangular fin, which has a wide tip at the end of the fin.

The primary aim of this study is to evaluate the thermal performance of the innovative U-Tube pipe configuration and compare it with the conventional single U-Tube type pipe configuration. In addition, the ground thermal properties for these two pipe configurations were estimated by using line source theory. In order to conduct TRTs, a small-scale experimental setup was designed, constructed, and commissioned in the laboratory at the University of Victoria, British Columbia, Canada.

\section{Small-Scale Experimental Apparatus and Theory}

\subsection{Small-Scale Experimental Apparatus}

The small-scale experimental apparatus comprises of three main parts: (i) VGHE (sand tank), (ii) water supply system, and (iii) data acquisition system.

A polyvinylchloride (PVC) borehole pipe (length, $1.05 \mathrm{~m}$; inner diameter, $7.5 \mathrm{~cm}$; outer diameter, $8.2 \mathrm{~cm}$ ) is placed at the center from the top of a sand tank (length, $1 \mathrm{~m}$; depth, $1.1 \mathrm{~m}$; width, $1 \mathrm{~m}$; wall thickness $2 \mathrm{~cm}$ ), and the space between the borehole and the tank is filled with dry silica sand up to the top of the borehole. Researchers proposed that testing times can be significantly reduced by using a radius of influence in the range of $0.5 \mathrm{~m}$ to $1.5 \mathrm{~m}$; this provides satisfactory temperature readings to determine thermal properties [26,27]. Figure 1 shows a photo of the small-scale test apparatus and Figure 2 is the schematic cross-section diagram of the same apparatus. Two different pipe configurations, including a conventional single U-Tube and an innovative U-Tube pipe configuration, are also inserted into the borehole at different times, and the space between the U-Tube pipe and the borehole wall is filled with grout (bentonite). Two thermistors (Omega TH-44032-1/4NPT-80; tolerance at $0-75^{\circ} \mathrm{C}: \pm 0.1^{\circ} \mathrm{C}$ ) are installed at the inlet and outlet of the VGHE to measure the inlet and outlet fluid temperatures (see Figure 2). The connecting pipes between the sand tank and the bath are insulated to minimize the heat transfer between the connecting pipes and the ambient air.

The conventional single U-Tube pipe consists of two copper pipes that have an inner diameter of $12.7 \mathrm{~mm}$ and outer diameter of $16 \mathrm{~mm}$ with a length of $1 \mathrm{~m}$. The innovative U-Tube pipe configuration consists of two copper pipes that have an inner diameter of $12.7 \mathrm{~mm}$ and outer diameter of $16 \mathrm{~mm}$ with a length of $1 \mathrm{~m}$. The fins are made of copper and have a cross-section of $8 \mathrm{~mm} \times 4 \mathrm{~mm}$, attached over the full height $(1 \mathrm{~m})$ of the U-Tube. Figure 3 shows the cross-section of the two different pipe configurations. The parameters for the two different pipe configurations of VGHEs are listed in Table 1. 


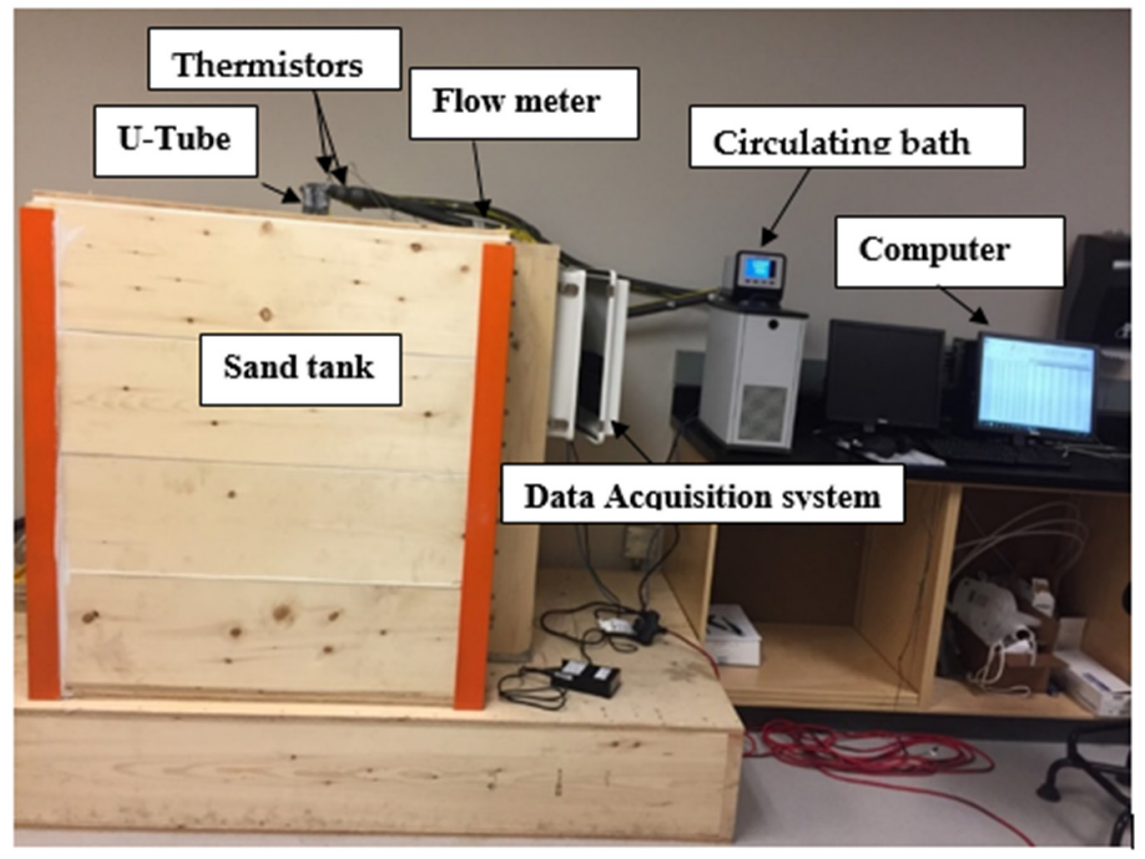

Figure 1. Photo of the small-scale experimental apparatus.

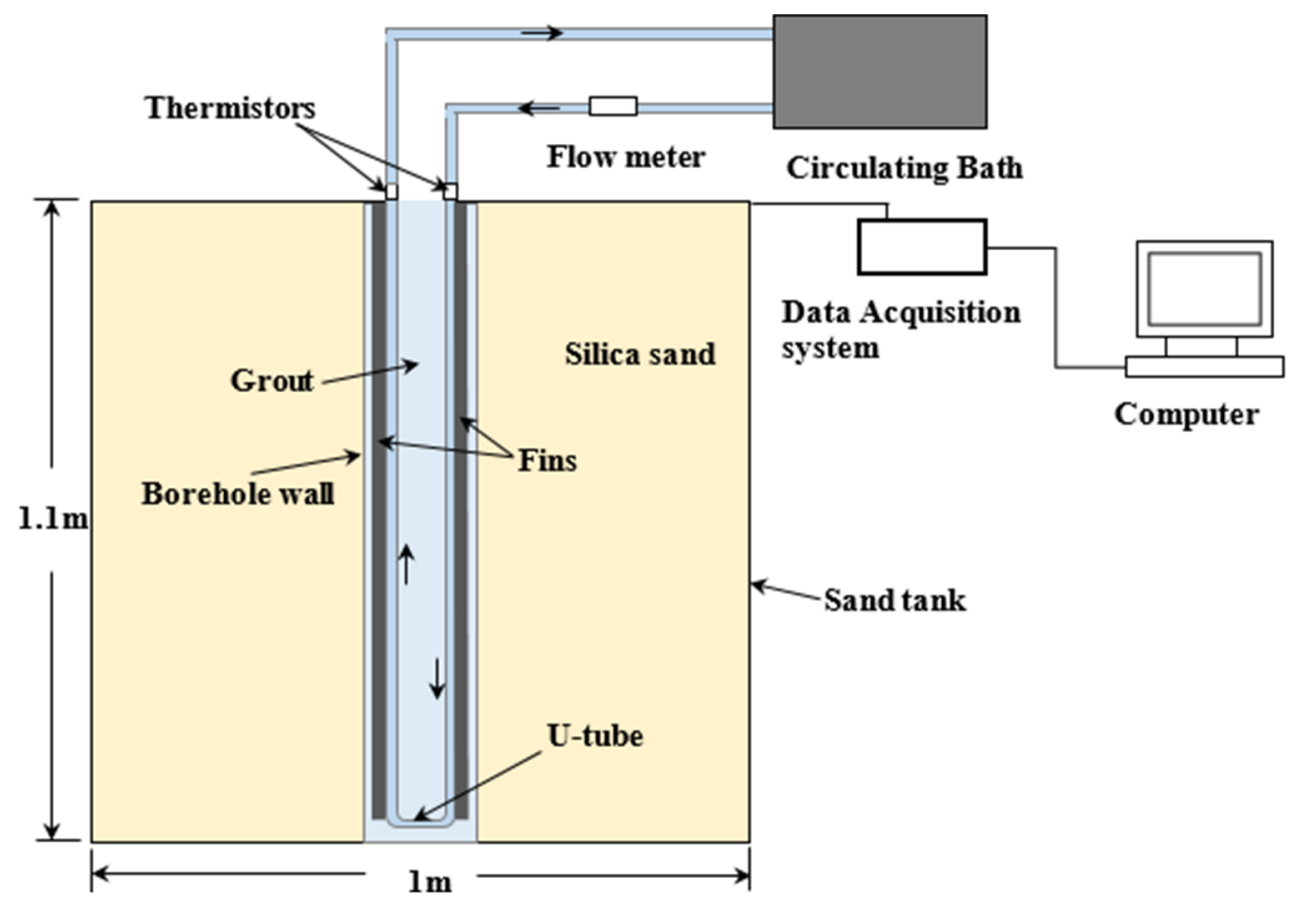

Figure 2. Schematic cross-section diagram of small-scale experimental apparatus.

A total of 64 thermocouples (EXPP-K-24) are distributed at specific distances inside the sand tank to measure the temperatures at different locations throughout the test and during the recovery time until the sand temperature reached the initial temperature. The thermocouples can measure a maximum temperature of $105^{\circ} \mathrm{C}$ with an accuracy of $\pm 0.75^{\circ} \mathrm{C}$. Each direction has 16 thermocouples, as shown in Figure 4. 

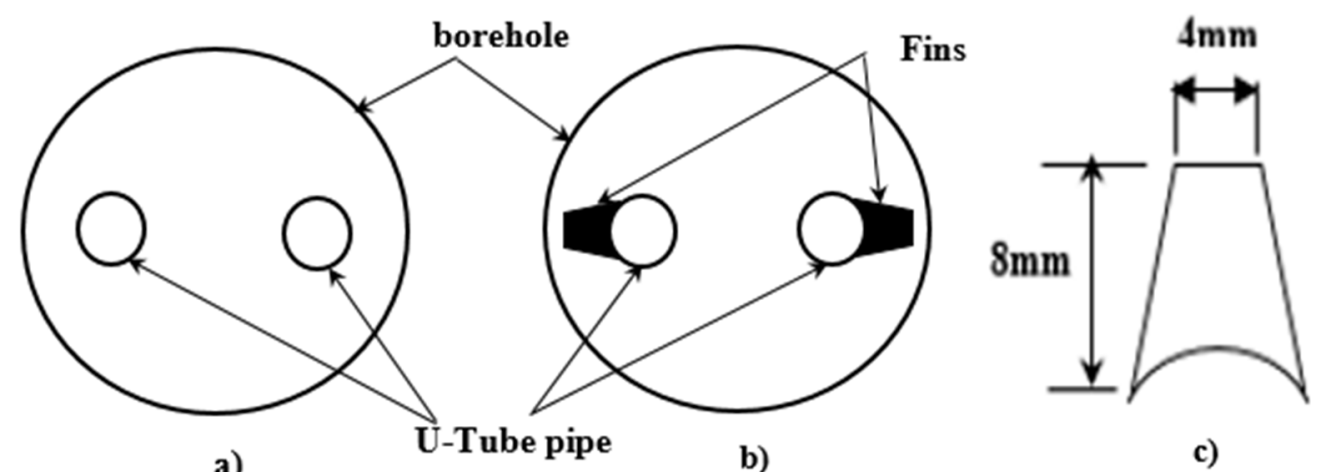

a)

b)

c)

Figure 3. Cross-section of the two different pipe configurations and the fin: (a) conventional single U-Tube; (b) innovative U-Tube pipe configuration; (c) cross section of the fin.

Table 1. Parameters for the two different pipe configurations of VGHEs.

\begin{tabular}{ccc}
\hline Parameters & Value & Unit \\
\hline U-Tube pipe outer diameter & 16 & $\mathrm{~mm}$ \\
U-Tube pipe inner diameter & 12.7 & $\mathrm{~mm}$ \\
Space between U-Tube pipes & 29 & $\mathrm{~mm}$ \\
Length of the U-Tube pipe & 1.05 & $\mathrm{~m}$ \\
Fin width & 400 & $\mathrm{~W} / \mathrm{m} \cdot \mathrm{K}$ \\
Fin length & 4 & $\mathrm{~mm}$ \\
Thermal conductivity of copper pipe [28] & 8 & $\mathrm{~mm}$ \\
Thermal conductivity of copper fin [28] & 400 & $\mathrm{~mm}$ \\
Borehole outer diameter (PVC) & 82 & $\mathrm{~mm}$ \\
Borehole inner diameter (PVC) & 75 & $\mathrm{~W} / \mathrm{m} \cdot \mathrm{K}$ \\
Thermal conductivity borehole wall (PVC) [28] & 0.19 & $\mathrm{~W} / \mathrm{m} \cdot \mathrm{K}$ \\
Thermal conductivity bentonite (grout) [29] & 0.8 & $\mathrm{~W} / \mathrm{m} \cdot \mathrm{K}$ \\
Thermal conductivity of silica sand (ground/soil) [12] & 2.42 & $\mathrm{~J} / \mathrm{kg} \cdot \mathrm{K}$ \\
Specific heat of silica sand [12] & 750 & $\mathrm{Kg} / \mathrm{m}{ }^{3}$ \\
Density of silica sand [12] & 1700 &
\end{tabular}

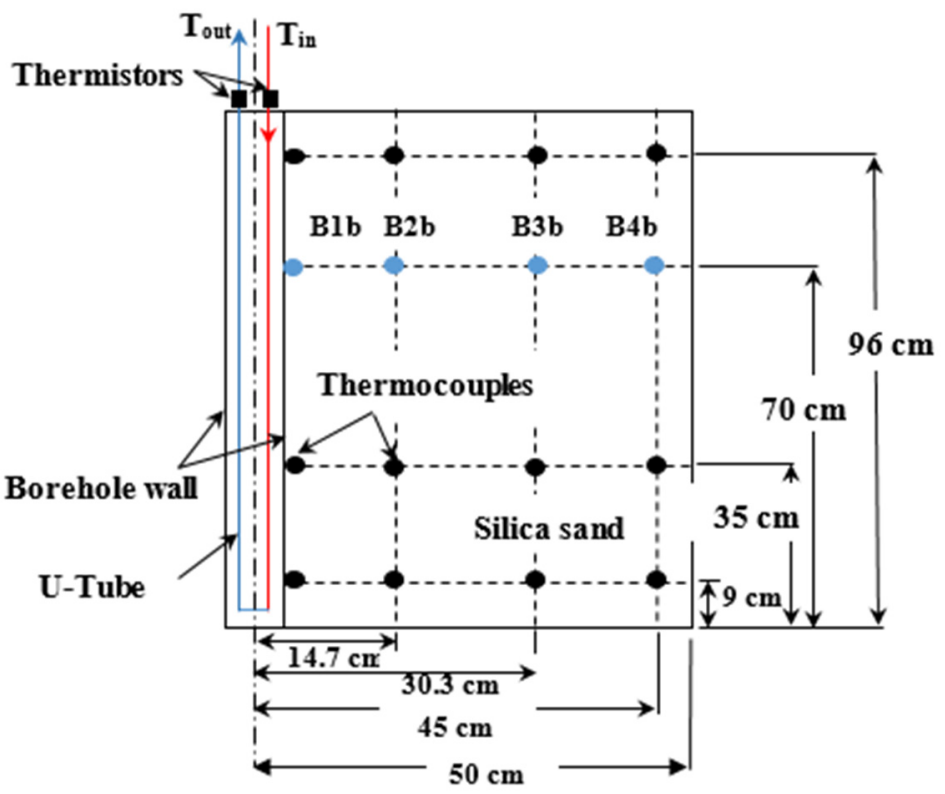

Figure 4. Front view for the 16 thermocouples at borehole wall and in silica sand at specific locations on the right side of sand tank. 


\subsection{Theory}

The goal of conducting TRT is to estimate the thermal (i.e., heat transfer) efficiency of the VGHE and also the thermal properties of the ground in field applications. The rate of the heat transfers per unit length (depth) of VGHE can be calculated from the relationship between the measured inlet and the outlet temperatures of the heat carrier fluid (water), which circulates through the VGHE, and its flow rate, as shown in Equation (1) $[12,24,30,31]$ :

$$
q=\frac{C_{p} \dot{m}\left(T_{\text {in }}-T_{\text {out }}\right)}{H}
$$

where $T_{\text {in }}$ is the inlet fluid temperature $\left({ }^{\circ} \mathrm{C}\right), T_{\text {out }}$ is the outlet fluid temperature $\left({ }^{\circ} \mathrm{C}\right), q$ is the heat exchange rate per unit borehole length $(\mathrm{W} / \mathrm{m}), C_{p}$ is the specific heat capacity of the circulating fluid $(\mathrm{J} / \mathrm{kg} \cdot \mathrm{K}), \dot{m}$ mass flow rate $(\mathrm{kg} / \mathrm{s})$, and $H$ is the borehole depth $(\mathrm{m})$.

To estimate the ground thermal properties, the line source model (LSM) is used in this research. Ingersoll and Plass (1948) reported that the infinite line source was used in the 1940s to calculate the ground temperature change over time for ground loop heat exchangers. The first field study was carried out to estimate the thermal conductivity of the ground by using this theory [32].

The temperature change in the ground is a function of radius $(r)$ from the borehole center and time $(t)$ with an injection of a constant amount of heat $(q)$ from the top to the bottom of the borehole that can be calculated by using the following equation [33-36]:

$$
T(r, t)=\frac{Q}{4 \pi \lambda_{e f f} H} \int_{\frac{r}{2 \pi k}}^{\infty} \frac{e^{-\beta^{2}}}{\beta} d \beta=\frac{Q}{4 \pi \lambda_{e f f} H} E_{1}\left(\frac{r^{2}}{4 \alpha t}\right)
$$

where $\lambda_{e f f}$ is the effective ground thermal conductivity $(\mathrm{W} / \mathrm{m} \cdot \mathrm{K})$, and $\alpha$ is the thermal diffusivity of the ground $\mathrm{m}^{2} / \mathrm{s}$. When the values of the parameter $\frac{\alpha t}{r^{2}}$ are large, it can be expressed with the following simple relation:

$$
E_{1}\left(\frac{\alpha t}{r^{2}}\right)=\ln \left(\frac{4 \alpha t}{r^{2}}\right)-\gamma
$$

where, $E_{1}$ is the exponential integral and $\gamma$ is Euler's constant (0.57721).

It is reported that the maximum error resulting from using the value of $\frac{\alpha t}{r^{2}} \geq 5 \mathrm{is} 10 \%$, and it is reduced to $2.5 \%$ when the value of $\frac{\alpha t}{r^{2}} \geq 20$ is used $[35,36]$.

The line source temperature at the borehole radius $\left(r_{b}\right)$, including the impact of the borehole thermal resistance $\left(R_{b}\right)$ between the heat carrier fluid and the borehole wall, was used to evaluate the mean fluid temperature $\left(T_{f}(t)\right)$. The fluid temperature as a function of time could be written in Equation (4) [30,33,35]:

$$
T_{f}(t)=\frac{Q}{4 \pi \lambda_{e f f} H} \ln (t)+\frac{Q}{H}\left[\frac{1}{4 \pi \lambda_{e f f}}\left\{\ln \left(\frac{4 \alpha}{r_{b}^{2}}\right)-\gamma\right\}+R_{b}\right]+T_{o}
$$

where $R_{b}$ is the borehole thermal resistance $(\mathrm{m} \cdot \mathrm{K} / \mathrm{W})$ and $T_{o}$ is the initial ground temperature $\left({ }^{\circ} \mathrm{C}\right)$.

The borehole thermal resistance can be expressed by the following equation:

$$
R_{b}=\frac{H}{Q}\left[T_{f}(t)-T_{o}\right]-\frac{1}{4 \pi \lambda_{e f f}}\left[\ln (t)+\ln \left(\frac{4 \alpha}{r_{b}^{2}}\right)-\gamma\right]
$$

It is noticed that the second and third terms on the right side of Equation (4) are constant. Therefore, it can be considered that the above equation is similar to the linear slope equation as $y=m \cdot x+b$. 
It is assumed that there is a linear relationship between the mean fluid temperature and the logarithm time $\ln (t)[33,36,37]$. They also expressed this relation by using the following equation:

$$
\begin{gathered}
T_{f}(t)=m \cdot \ln (t)+b \\
\text { Slope }=m=\frac{q}{4 \pi \lambda_{e f f}} \rightarrow \lambda_{e f f}=\frac{q}{4 \pi m}
\end{gathered}
$$

\section{Analysis of Experimental Results}

Effective Ground Thermal Conductivity and Borehole Thermal Resistance

Two different approaches can be used to estimate the initial ground temperature before the TRT started [38]. The first approach is to calculate the initial ground temperature with still water in the U-Tube. The inlet and outlet borehole temperatures and the ground temperature at 64 locations in the sand tank are recorded every $1 \mathrm{~min}$ for about $1 \mathrm{~h}$ by using the data acquisition system. The second approach is to circulate the water in a close system through the VGHE for about $1 \mathrm{~h}$ and without adding heat during the test. Nevertheless, there was no heat injection during this period, but at the same time, some heat would be added into the system by the pump. Then, the inlet and outlet borehole temperatures and the ground temperatures at the 64 locations in the sand tank were recorded every $1 \mathrm{~min}$ for $1 \mathrm{~h}$ by using the data acquisition system. In this study, the first approach is used to estimate the average initial ground temperature. The U-Tube in the VGHE wall was filled with water for 7 days before the measurement started. The average initial ground temperature was calculated to be $17.58^{\circ} \mathrm{C}$.

After the average initial ground temperature was calculated as shown before by using first approach, the TRT was conducted for $130 \mathrm{~h}(60 \mathrm{~h}$ for the heat injection and $70 \mathrm{~h}$ to let the sand return to its initial ground temperature). A constant heat injection rate was used throughout the TRT. The outlet fluid temperature leaving from the circulating bath and entering to the VGHE was set to be $50{ }^{\circ} \mathrm{C}$ with a constant volumetric flow rate $(V)$ of $0.730 \mathrm{~L} / \mathrm{min}$. The inlet and outlet fluid temperatures of the borehole were recorded every 5 min by using the data acquisition system. As shown in Figure 5, the difference between the inlet and outlet temperatures was $0.82{ }^{\circ} \mathrm{C}$ after $1 \mathrm{~h}$. The temperature difference then gradually decreased to $0.52{ }^{\circ} \mathrm{C}$ after $30 \mathrm{~h}$, and it decreased further to $0.4{ }^{\circ} \mathrm{C}$ after $60 \mathrm{~h}$.

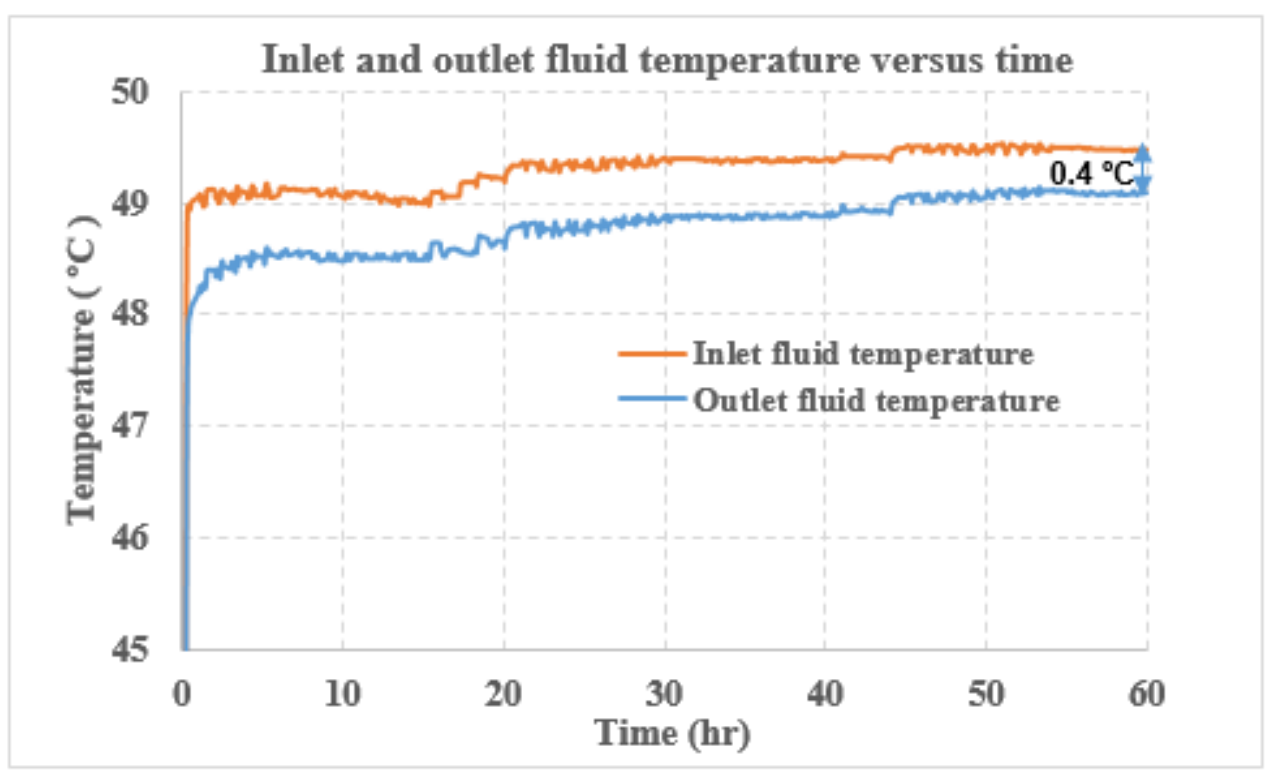

Figure 5. Inlet and outlet fluid temperature for the conventional single U-Tube VGHE during heat injection. 
As shown in Equation (6), there is a linear relationship between $T_{f}$ and $\ln (t)$. The slope $(m)=0.6189$ was calculated from Figure 6, and then substituting ' $m$ ' in the Equation (7), $\lambda_{\text {eff }}$ was calculated as $3.92 \mathrm{~W} / \mathrm{m} \cdot \mathrm{K}$.

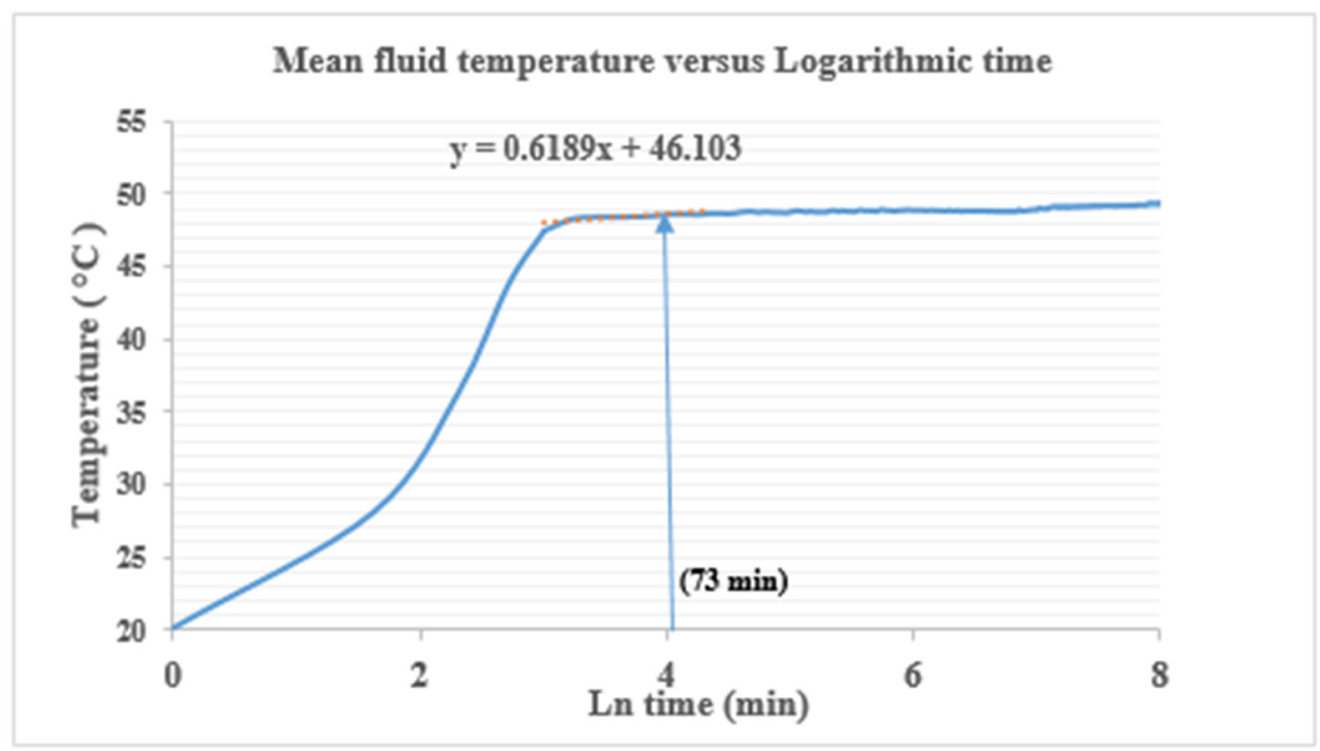

Figure 6. Mean fluid temperature plotted versus logarithmic time, conventional single U-Tube VGHE.

Using Equation (1) and from the measured inlet $\left(T_{\text {in }}\right)$ and outlet $\left(T_{\text {out }}\right)$ temperatures, the heat exchange rate per unit length (q) of VGHE was calculated. The borehole thermal resistance $\left(R_{b}\right)$ was calculated using the value of $\lambda_{e f f}(3.92 \mathrm{~W} / \mathrm{m} \cdot \mathrm{K})$ in Equation (5). The value of borehole thermal resistance $\left(R_{b}\right)$ at $t>5 r 2 / \alpha$ (i.e., $73 \mathrm{~min}$, error $10 \%$ ), was found to be $0.961 \mathrm{~m} \cdot \mathrm{K} / \mathrm{W}$. Calculated results are presented in Table 2.

Table 2. Comparison values of $\Delta T, V, q$, $\lambda$ eff, and $R_{b}$ for the two pipe configurations.

\begin{tabular}{|c|c|c|c|c|c|}
\hline Pipe Configurations & $\Delta T$ at $60 \mathrm{~h}{ }^{\circ} \mathrm{C}$ & $V(\mathrm{~L} / \mathrm{min})$ & $q$ at $60 \mathrm{~h}(\mathrm{~W} / \mathrm{m})$ & $\lambda e f f(\mathbf{W} / \mathbf{m} \cdot \mathbf{K})$ & $R_{b}(\mathrm{~m} \cdot \mathrm{K} / \mathrm{W})$ \\
\hline Single U-Tube pipe & 0.4 & 0.729 & 19.05 & 3.92 & 0.961 \\
\hline innovative single U-Tube & 0.7 & 0.703 & 30.09 & 4.85 & 0.680 \\
\hline
\end{tabular}

Four thermocouples, B1b, B2b, B3b, and B4b, were fixed on the right hand side of the borehole wall at $14.70,30.30$, and $45.00 \mathrm{~cm}$, respectively, from the center of the borehole, at a height of $700 \mathrm{~cm}$ from the bottom of the sand tank. The four thermocouples (EXPP$\mathrm{K}-24)$ measure the maximum temperature of $105^{\circ} \mathrm{C}$ with an accuracy of $\pm 0.75{ }^{\circ} \mathrm{C}$. Before conducting the test, the initial ground temperature of $\mathrm{B} 4 \mathrm{~b}, \mathrm{~B} 3 \mathrm{~b}, \mathrm{~B} 2 \mathrm{~b}$, and $\mathrm{B} 1 \mathrm{~b}$ were $17.75^{\circ} \mathrm{C}$, $17.98{ }^{\circ} \mathrm{C}, 18.06{ }^{\circ} \mathrm{C}$, and $18.09{ }^{\circ} \mathrm{C}$, respectively, and they increased after $60 \mathrm{~h}$ during the heat injection to $36.16{ }^{\circ} \mathrm{C}, 25.73{ }^{\circ} \mathrm{C}, 20.52{ }^{\circ} \mathrm{C}$, and $19.95{ }^{\circ} \mathrm{C}$, respectively. The ground temperatures of the $\mathrm{B} 4 \mathrm{~b}, \mathrm{~B} 3 \mathrm{~b}, \mathrm{~B} 2 \mathrm{~b}$, and $\mathrm{B} 1 \mathrm{~b}$ decreased to $18.2^{\circ} \mathrm{C}, 18.28^{\circ} \mathrm{C}, 18$, and $17.71{ }^{\circ} \mathrm{C}$, respectively, after $70 \mathrm{~h}$ from the end of the test, as shown in Figure 7 . However, the ground temperature changed rapidly and reached $36.16^{\circ} \mathrm{C}$ after $60 \mathrm{~h}$ at the borehole wall. It changed slowly away from the borehole at $45 \mathrm{~cm}$ from the center of the borehole and reached $19.95^{\circ} \mathrm{C}$. The ambient temperature was recorded during the TRT and recovery time by using a dada logger (OM 62), and it was confined at a range of $14.64{ }^{\circ} \mathrm{C}$ to $20.48^{\circ} \mathrm{C}$. The temperature measurement for the OM- 62 was at a range of $-40{ }^{\circ} \mathrm{C}$ to $70{ }^{\circ} \mathrm{C}$ with an accuracy of \pm 0.5 . 


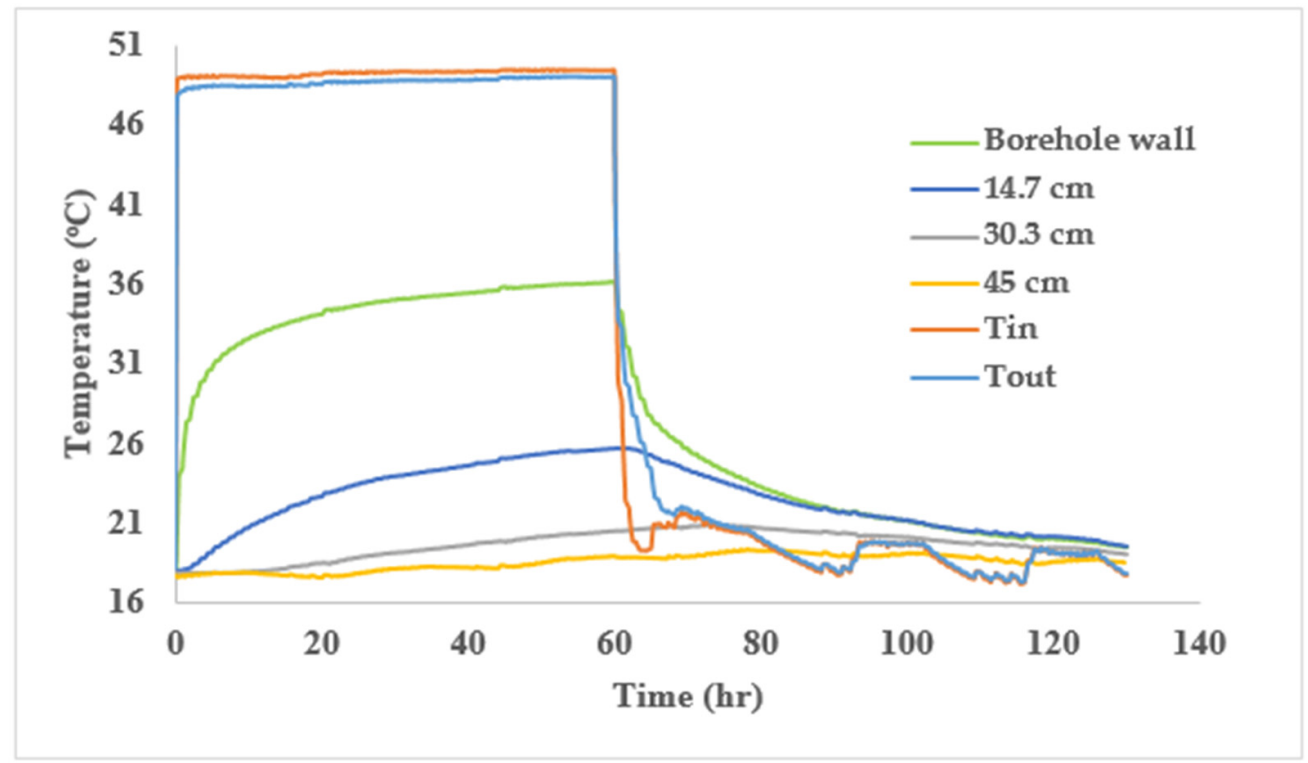

Figure 7. Temperature measurement at the inlet (Tin) and the outlet (Tout), borehole wall, and in sand at different locations from the borehole wall, conventional single U-Tube VGHE.

Another TRT was performed for the innovative U-Tube pipe configuration with the similar boundary conditions used with the conventional single U-Tube. The average initial ground temperature was calculated to be $19.91^{\circ} \mathrm{C}$ before the TRT started.

The TRT was conducted for $145 \mathrm{~h}$ ( $65 \mathrm{~h}$ for the heat injection and $80 \mathrm{~h}$ to let the system return to its initial ground temperature). A constant heat injection rate was used throughout the TRT. The outlet fluid temperature leaving from the bath and entering to the VGHE was set to be $50{ }^{\circ} \mathrm{C}$ with a constant volumetric flow rate of $0.703 \mathrm{~L} / \mathrm{min}$. The difference between the inlet and outlet temperatures was $0.97^{\circ} \mathrm{C}$ after $1 \mathrm{~h}$. The temperature difference then gradually decreased to $0.7^{\circ} \mathrm{C}$ after $30 \mathrm{~h}$, and it got to $0.65^{\circ} \mathrm{C}$ after $60 \mathrm{~h}$ as shown in Figure 8.

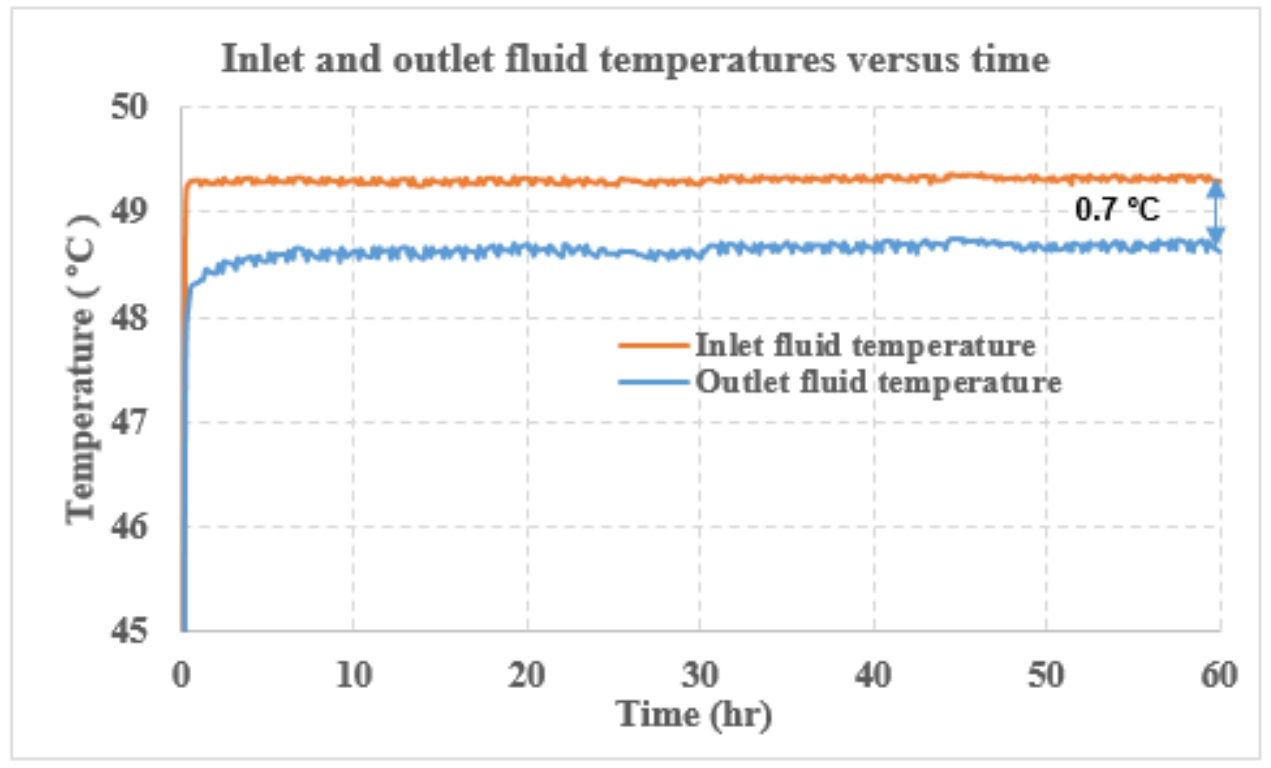

Figure 8. Inlet and outlet fluid temperature for the innovative U-Tube pipe VGHE, during heat injection. 
As shown in Equation (6), there is a linear relationship between $T_{f}$ and $\ln (t)$. The slope $(\mathrm{m})=0.6642$ was calculated from Figure 9, and then substituting ' $\mathrm{m}$ ' in the Equation (7), $\left(\lambda_{e f f}\right)$ was calculated as $4.85 \mathrm{~W} / \mathrm{m} \cdot \mathrm{K}$.

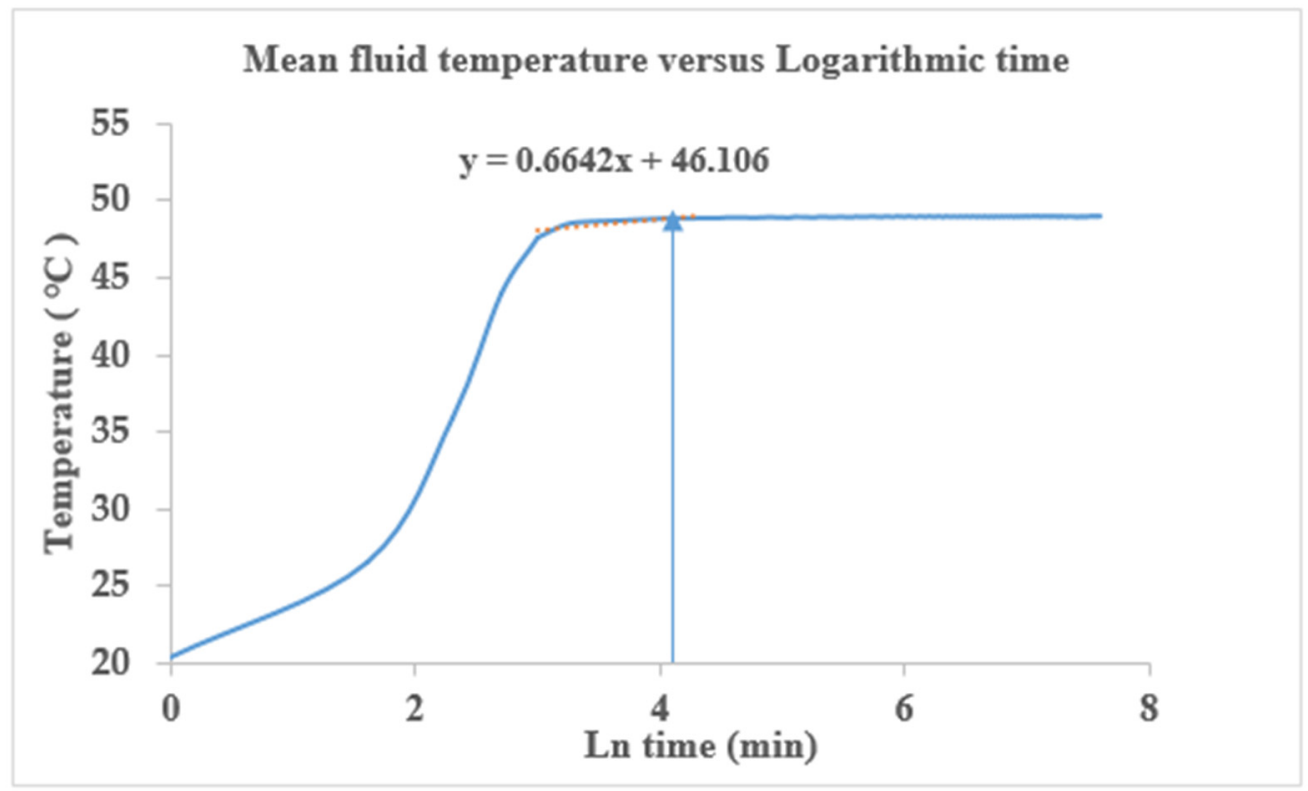

Figure 9. Mean fluid temperature plotted versus logarithmic time, innovative U-Tube pipe VGHE.

Using Equation (1) and from the measured inlet (Tin) and outlet (Tout) temperatures, the heat exchange rate per unit length (q) of VGHE was calculated. The value of borehole thermal resistance $\left(R_{b}\right)$ was calculated using the value of $\lambda_{\text {eff }}(4.85 \mathrm{~W} / \mathrm{m} \cdot \mathrm{K})$ in Equation (5). The value of borehole thermal resistance $\left(R_{b}\right)$ at $\mathrm{t}>5 \mathrm{r} 2 / \alpha$ (i.e., $73 \mathrm{~min}$, error $10 \%$ ), was found to be $0.680 \mathrm{~m} \cdot \mathrm{K} / \mathrm{W}$. Calculated results are presented in Table 2 .

As shown in Figure 10, the initial ground temperature of B4b, B3b, B2b, and B1b were $21.08^{\circ} \mathrm{C}, 22.02{ }^{\circ} \mathrm{C}, 21.72{ }^{\circ} \mathrm{C}$, and $21.09^{\circ} \mathrm{C}$, respectively, and they increased after $60 \mathrm{~h}$ during the heat injection to $41.03{ }^{\circ} \mathrm{C}, 29.28{ }^{\circ} \mathrm{C}, 23.71{ }^{\circ} \mathrm{C}$, and $21.69^{\circ} \mathrm{C}$, respectively. The ground temperatures of the $\mathrm{B} 4 \mathrm{~b}, \mathrm{~B} 3 \mathrm{~b}, \mathrm{~B} 2 \mathrm{~b}$, and $\mathrm{B} 1 \mathrm{~b}$ decreased to $20.26^{\circ} \mathrm{C}, 20.55{ }^{\circ} \mathrm{C}, 19.74{ }^{\circ} \mathrm{C}$, and $18.5^{\circ} \mathrm{C}$, respectively, after $80 \mathrm{~h}$ from the end of the test as shown in Figure 10. However, the ground temperature changed rapidly and reached to $41.03^{\circ} \mathrm{C}$ after $60 \mathrm{~h}$ at the borehole wall. It changed slowly away from the borehole at $45 \mathrm{~cm}$ from the center of the borehole and reached $21.69^{\circ} \mathrm{C}$. The ambient temperature was recorded during the TRT and recovery time by using a data logger (OM-62), and it was confined at a range of $14.84^{\circ} \mathrm{C}$ to $21.32{ }^{\circ} \mathrm{C}$.

Table 2 presents the difference between the inlet and outlet fluid temperatures $(\Delta T)$, volumetric flow rate $(V)$, heat injection rate $(q)$, effective ground thermal conductivity $\left(\lambda_{\text {eff }}\right)$, and borehole thermal resistance $\left(R_{b}\right)$ for the two different pipe configurations. 


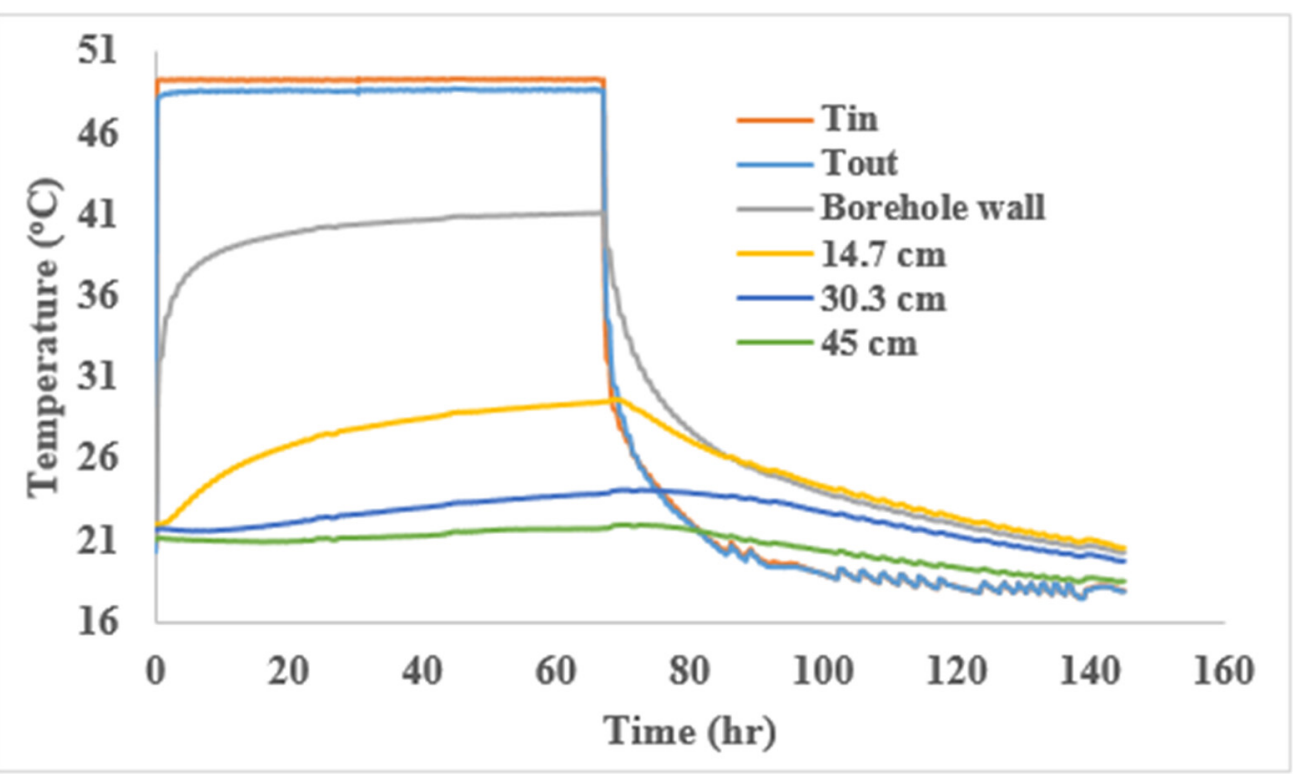

Figure 10. Temperature at the inlet (Tin) and the outlet (Tout), borehole wall, and in sand at different locations from the borehole wall, innovative U-Tube pipe VGHE.

\section{Discussion}

\subsection{Experimental Observations}

Two TRTs were conducted in the laboratory for the two different pipe configurations under similar boundary conditions to demonstrate the impact of innovative U-Tube pipe configuration on the heat transfer rate of the VGHE. The two different pipe configurations are the conventional single U-Tube and the innovative pipe configuration (the conventional single U-Tube pipe with fins), as shown in Figure 3. The two TRTs are continued for a period of $60 \mathrm{~h}$. As shown in Figures 5 and 8, after $60 \mathrm{~h}$ from starting the test, the difference between the inlet and outlet fluid temperatures was $0.4^{\circ} \mathrm{C}$ for the conventional single U-Tube pipe VGHE while it was $0.7^{\circ} \mathrm{C}$ for innovative U-Tube pipe configuration VGHE. The latter was increased by $0.29^{\circ} \mathrm{C}$. As would be expected, the borehole thermal resistance also decreased from $0.961 \mathrm{~m} \cdot \mathrm{K} / \mathrm{W}$ to $0.680 \mathrm{~m} \cdot \mathrm{K} / \mathrm{W}$ due to the introduction of external fins to the conventional single U-Tube (see Table 2). The effective ground thermal conductivity is $3.92 \mathrm{~W} / \mathrm{m} \cdot \mathrm{K}$ for the conventional single U-Tube pipe configuration, and it is $4.85 \mathrm{~W} / \mathrm{m} \cdot \mathrm{K}$ for the innovative U-Tube pipe configuration. The results also indicate that that the heat exchange rate for the innovative U-Tube pipe configuration was $30.09 \mathrm{~W} / \mathrm{m}$, i.e., an increase of $11.04 \mathrm{~W} / \mathrm{m}$ compared to the conventional single U-Tube (see Table 2). The results also show that the temperature at the borehole wall increased by $4.87^{\circ} \mathrm{C}$ when the innovative U-Tube pipe configuration was used compared to the conventional single U-Tube. With the innovative U-Tube pipe configuration, at $45 \mathrm{~cm}$ from the center of the borehole and at different depths, the highest temperature increased by $0.54{ }^{\circ} \mathrm{C}$ more than the conventional single U-Tube pipe configuration as shown in Figures 7 and 10. Based on the aforementioned observations, it can be concluded that substantial improvement of thermal efficiency of VGHE can be made by the introduction of external fins to the conventional single U-Tube pipe. In practical terms, it means fewer boreholes are required when conventional single U-Tube pipes are replaced by the innovative U-Tube pipe configuration with external fins, and this, in turn, will reduce the VGHE installation cost.

\subsection{Sources of Uncertainty or Error}

The sources of error or uncertainty in measured parameters during the thermal response tests (TRTs) and their impacts on the results obtained from the tests in the laboratory could be explained qualitatively but difficult to quantify adequately. These sources of error 
arise from the assumptions made regarding the properties of the materials, application of the line source theory, sensors, etc. [39]. Quantification of uncertainties arising from these sources is not only beyond the scope of this paper, but a systemic evaluation protocol for this purpose is yet to be established. However, it is well known that the errors associated with measured inlet and outlet temperatures, using two thermistors (Omega TH-44032-1/4NPT-80), have a significant impact on the overall error or uncertainty of the test results [39]. The error associated with each of these two measured temperatures is $\pm 0.1^{\circ} \mathrm{C}$ at 0 to $75^{\circ} \mathrm{C}$. The propagation of this error due to subtraction can be calculated by square rooting the sum of the square of each errors (i.e., $\sqrt{(0.1)^{2}+\left(0.1^{2}\right)}= \pm 0.14^{\circ} \mathrm{C}$ ).

\section{Conclusions}

The results from the TRTs conducted in the laboratory on a small-scale VGHE with two different pipe configurations, a conventional single U-Tube and the same with external fins, have been presented and examined in this paper. The main observations are outlined below:

- The difference between the inlet and outlet temperature for the innovative U-Tube pipe configuration (i.e., with external fins) is $0.7^{\circ} \mathrm{C}$ after $60 \mathrm{~h}$ while the difference between the inlet and outlet temperatures for the conventional single U-Tube pipe configuration was $0.4{ }^{\circ} \mathrm{C}$ after $60 \mathrm{~h}$. Thus, a $76.3 \%$ increase in temperature difference has been achieved due to the use of innovative pipe configuration.

- The effective ground thermal conductivity for the innovative U-Tube pipe configuration was $4.85 \mathrm{~W} / \mathrm{m} \cdot \mathrm{K}$, a $23.64 \%$ increase compared to the conventional single U-Tube pipe configuration.

- The borehole thermal resistance for the innovative U-Tube pipe configuration was found to be $0.680 \mathrm{~m} \cdot \mathrm{K} / \mathrm{W}$, which is $29.22 \%$ lower than that of the same with conventional single U-Tube pipe.

- The increased ground temperatures with the innovative U-Tube pipe configuration, compared to single U-Tube pipe configuration, clearly indicate the superior heat transfer performance of innovative pipe configuration.

- The introduction of external fins to single U-Tube pipe configuration helps to reduce the number of boreholes by about $57.95 \%$, which will in turn decrease the installation cost.

Author Contributions: Conceptualization, A.E. and P.M.; methodology, A.E.; formal analysis, A.E. and P.M.; investigation, A.E.; resources, P.M.; writing—original draft preparation, A.E. and P.M.; writing—-review and editing, P.M.; supervision, P.M.; project administration, P.M.; funding acquisition, P.M. All authors have read and agreed to the published version of the manuscript.

Funding: The graduate student (A.E.) was funded by the Libyan-North American Scholarship Program (LNASP), which is a joint collaboration between the Libyan Ministry of Higher Education and Scientific Research and the Canadian Bureau for International Education.

Institutional Review Board Statement: Not applicable.

Informed Consent Statement: Not applicable.

Data Availability Statement: Not applicable.

Acknowledgments: The authors would like to acknowledge the scientific and technical knowledge supports provided by Andrew Rowe, Armando Tura, Mitchell Anderson, Matthew Walker, and Robert Lepage.

Conflicts of Interest: The authors declare no conflict of interest. The funders had no role in the design of the study; in the collection, analyses, or interpretation of data; in the writing of the manuscript, or in the decision to publish the results. 


\section{References}

1. Muraya, K.N. Numerical Modeling of the Transient Thermal Interference of Vertical U-Tube Heat Exchangers. Ph.D. Thesis, Texas A\&M University, College Station, TX, USA, 1994.

2. Bidarmaghz, A.; Narsilio, G.; Johnston, I. Numerical modelling of ground heat exchangers with different ground loop configurations for direct geothermal applications. In Proceedings of the 18th International Conference on Soil Mechanics and Geotechnical Engineering 2013, Paris, France, 2-6 September 2013; pp. 2-6.

3. Sanner, B.; Hellström, G.; Spitler, J.; Gehlin, S. Thermal response test-current status and world-wide application. In Proceedings of the World Geothermal Congress, Antalya, Turkey, 24-29 April 2005; Volume 1436, p. 2005.

4. Gu, Y.; O'Neal, D.L. Modeling the effect of backfills on U-tube ground coil performance. Ashrae Trans. 1998, $104,356$.

5. Pahud, D.; Matthey, B. Comparison of the thermal performance of double U-pipe borehole heat exchangers measured in situ. Energy Build. 2001, 33, 503-507. [CrossRef]

6. Zeng, H.; Diao, N.; Fang, Z. Heat transfer analysis of boreholes in vertical ground heat exchangers. Int. J. Heat Mass Transf. 2003, 46, 4467-4481. [CrossRef]

7. Esen, H.; Inalli, M. Temperature distributions in boreholes of a vertical ground-coupled heat pump system. Renew. Energy 2009, 34, 2672-2679. [CrossRef]

8. Acuña, J.; Palm, B. A novel coaxial borehole heat exchanger: Description and first distributed thermal response test measurements. In Proceedings of the World Geothermal Congress 2010, Bali, Indonesia, 25-29 April 2010; p. 7.

9. Lee, C.; Park, M.; Min, S.; Kang, S.-H.; Sohn, B.; Choi, H. Comparison of effective thermal conductivity in closed-loop vertical ground heat exchangers. Appl. Therm. Eng. 2011, 31, 3669-3676. [CrossRef]

10. Beier, R.A.; Ewbank, G.N. In-Situ Test Thermal Response Tests Interpretations. OGEE Ground Source Heat Exchange Study; Oklahoma State University: Stillwater, OK, USA, 2012.

11. Desmedt, J.; Van Bael, J.; Hoes, H.; Robeyn, N. Experimental performance of borehole heat exchangers and grouting materials for ground source heat pumps. Int. J. Energy Res. 2012, 36, 1238-1246. [CrossRef]

12. Haddada, J.; Miyara, A. Performance Investigation of Multiple-Tube Ground Heat Exchangers for Ground-Source Heat Pump. Am. J. Energy Eng. 2014, 2, 103-107.

13. Kramer, C.A.; Basu, P. Performance of a model geothermal pile in sand. In Proceedings of the 8th International Conference on Physical Modelling in Geotechnics 2014 (ICPMG2014), Perth, Australia, 14-17 January 2014; Gaudin, C., White, D., Eds.; CRC Press/Balkema: Leiden, The Netherlands, 2014; pp. 771-777.

14. Salim Shirazi, A.; Bernier, M. A small-scale experimental apparatus to study heat transfer in the vicinity of geothermal boreholes. HVACER Res. 2014, 20, 819-827.

15. Erol, S.; François, B. Efficiency of various grouting materials for borehole heat exchangers. Appl. Therm. Eng. 2014, 70, 788-799. [CrossRef]

16. Cimmino, M.; Bernier, M. Experimental determination of the g-functions of a small-scale geothermal borehole. Geothermics 2015, 56, 60-71. [CrossRef]

17. Liu, X.; Xiao, Y.; Inthavong, K.; Tu, J. Experimental and numerical investigation on a new type of heat exchanger in ground source heat pump system. Energy Effic. 2015, 8, 845-857. [CrossRef]

18. Ramadan, A.S. Parametric Study of Vertical Ground Loop Heat Exchangers for Ground Source Heat Pump Systems. Master's Thesis, University of Western Ontario, London, ON, Canada, 2016.

19. Chang, K.S.; Kim, M.J. Thermal performance evaluation of vertical U-loop ground heat exchanger using in-situ thermal response test. Renew. Energy 2016, 87, 585-591. [CrossRef]

20. Luo, J.; Zhao, H.; Gui, S.; Xiang, W.; Rohn, J.; Blum, P. Thermo-economic analysis of four different types of ground heat exchangers in energy piles. Appl. Therm. Eng. 2016, 108, 11-19. [CrossRef]

21. Serageldin, A.A.; Sakata, Y.; Katsura, T.; Nagano, K. Thermo-hydraulic performance of the U-tube borehole heat exchanger with a novel oval cross-section: Numerical approach. Energy Convers. Manag. 2018, 177, 406-415. [CrossRef]

22. Bae, S.M.; Nam, Y.; Choi, J.M.; Lee, K.H.; Choi, J.S. Analysis on thermal performance of ground heat exchanger according to design type based on thermal response test. Energies 2019, 12, 651. [CrossRef]

23. Li, W.; Li, X.; Peng, Y.; Wang, Y.; Tu, J. Experimental and numerical investigations on heat transfer in stratified subsurface materials. Appl. Therm. Eng. 2018, 135, 228-237. [CrossRef]

24. Liang, B.; Chen, M.; Fu, B.; Li, H. Investigation on the thermal and flow performances of a vertical spiral-tube ground heat exchanger in sand combined with kaolin additive. Energy Build. 2019, 190, 235-245. [CrossRef]

25. Eswiasi, A. Novel Pipe Configuration for Enhanced Efficiency of Vertical Ground Heat Exchanger. Ph.D. Thesis, University of Victoria, Victoria, BC, Canada, 2021.

26. Raymond, J.; Therrien, R.; Gosselin, L.; Lefebvre, R. A Review of Thermal Response Test Analysis Using Pumping Test Concepts. Ground Water 2011, 49, 932-945. [CrossRef] [PubMed]

27. Zhang, C.; Guo, Z.; Liu, Y.; Cong, X.; Peng, D. A review on thermal response test of ground-coupled heat pump systems. Renew. Sustain. Energy Rev. 2014, 40, 851-867. [CrossRef]

28. Salimshirazi, A. Transient Heat Transfer in Vertical Ground Heat Exchangers. Ph.D. Thesis, École Polytechnique de Montréal, Montreal, QC, Canada, 2012.

29. Geothermal Grout ${ }^{\mathrm{TM}}$, Technical Data, Cetco Building Products. Available online: www.cetco.com/dpg (accessed on 3 June 2021). 
30. Choi, W.; Ooka, R. Effect of natural convection on thermal response test conducted in saturated porous formation: Comparison of gravel-backfilled and cement-grouted borehole heat exchangers. Renew. Energy 2016, 96, 891-903. [CrossRef]

31. Zhou, T.; Chen, M.; Liang, B. Thermal performance of a ground U-shaped tube with twisted tapes in sand/graphite backfill materials. Exp. Heat Transf. 2021, 34, 186-200. [CrossRef]

32. Mogensen, P. Fluid to duct wall heat transfer in duct system heat storages. Doc. Swed. Counc. Build. Res. $1983,652-657$.

33. Eklöf, C.; Gehlin, S. TED-a Mobile Equipment for Thermal Response Test: Testing and Evaluation; Luleå University of Technology: Luleå, Sweden, 1996. Available online: https://www.researchgate.net/publication/242072965_A_Mobile_Equipment_for_ Thermal_Response_Test (accessed on 3 June 2021).

34. Austin, W.A., III. Development of An In Situ System for Measuring Ground Thermal Properties. Ph.D. Thesis, Oklahoma State University, Stillwater, OK, USA, 1998.

35. Gehlin, S. Thermal Response Test: Method Development and Evaluation. Ph.D. Thesis, Department of Environmental Division of Water Resources Engineering, Lulea University, Lulea, Sweden, 2002.

36. You, J.; Lee, C. Analysis of effective thermal conductivity stability of geothermal heat exchanger according to ambient environmental conditions. Int. J. Energy Res. 2019, 43, 7682-7692. [CrossRef]

37. Loveridge, F.; Olgun, C.G.; Brettmann, T.; Powrie, W. The Thermal Behaviour of Three Different Auger Pressure Grouted Piles Used as Heat Exchangers. Geotech. Geol. Eng. 2015, 33, 273-289. [CrossRef]

38. Gehlin, S.; Nordell, B. Determining undisturbed ground temperature for thermal response test. ASHRAE Trans. 2003, 109, 151-156.

39. Witte, H.J.L. Error analysis of thermal response tests. Appl. Energy 2013, 109, 302-311. [CrossRef] 